\title{
ALTERATIONS OF SIZE CONSTANCY ASSOCIATED WITH BRAIN LESIONS IN MAN*
}

\author{
BY
}

\author{
MARIA WYKE
}

\section{From the Psychological Laboratory, Institute of Neurology, National Hospital, Queen Square, London}

Constancy of visual perception is of special behavioural importance in man, for it is one of the bases of his spatial orientation, and is manifest in several spheres of visual experience.

For example, the perception of the size of objects is relatively independent of their distance from the observer. Thus if one inspects two pennies, the first at a distance of three feet and the second twice as far away, the nearer penny does not look anything like twice as big as the more distant one, even though the dimensions of the retinal image of the more distant coin are half those of the image of the nearer one.

Apparent shape provides yet another example of visual constancy. For the perceived shape of an object exhibits considerable stability, in spite of the fact that the geometry of its retinal image constantly changes as an individual moves in relation to the object, or the object in relation to an observer. In either circumstances the object appears always to be more or less the same shape, no matter how it be viewed: if a penny is watched while slowly tilting it through $45^{\circ}$ it continues to appear more or less round, in spite of the fact that the image projected on the retina gradually assumes the form of an ellipse.

The visual perception of size-distance relations may be affected by a number of factors, such as reduction of visual cues, changes in illumination and in the angular separation of the objects viewed, and the effect of attitude (Wyke, 1959). However, previous studies (Vernon, 1952) have shown that under binocular viewing conditions providing abundant visual cues, and in response to specific instructions, it is possible for normal individuals to produce perceptual judgments close to size constancy.

The optical properties of the eye cannot provide the means for making size constancy judgments (Fig. 1). This phenomenon must therefore involve

*This paper is based on work carried out in fulfilment of the requirements for the degree of Ph.D. in the University of London. central nervous mechanisms additional to those of the retina and its primary afferent projections.

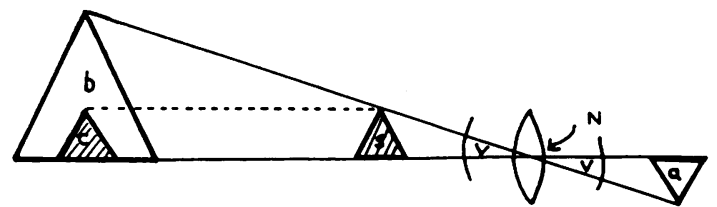

Fig. 1.-A diagram illustrating the principle of size constancy judgment.

Evidence of this is provided by the clinical observation that alterations in the apparent size of visual objects are sometimes described by patients with brain lesions that do not involve the primary visual pathways. Such alterations are noted in two different circumstances. First, they may appear as transient pre-ictal phenomena in seizures of temporal lobe origin; or second, they may occur as persisting disturbances of perception of size and distance in association with lesions of the parietal lobes.

Patients with irritative lesions in one or other temporal lobe (e.g., Penfield and Jasper, 1954) may experience seizures that begin with brief alterations in the apparent size, shape, or distance of objects in the visual field. According to Penfield (loc. cit.), these phenomena are not disturbances of vision itself but represent a misinterpretation of visual experience and as such they are illusional in character. For this reason, seizures of this type have been classified by Penfield (1947) as "psychical".

On the other hand, destructive lesions of the parietal lobes may result in persisting alterations in the perception of size, and in distance judgment. Thus, alterations in the apparent size of objects were reported in 1919 by Holmes in six cases with posttraumatic lesions in the posterior parts of both cerebral hemispheres; and similar visual disorders in patients with parietal lesions have been reported more recently by Bender and Teuber $(1947,1948)$. 
TABLE I

VISUAL PERCEPTUAL DISORDERS IN CASES WITH BRAIN LESIONS

\begin{tabular}{|c|c|c|c|c|}
\hline Author & $\begin{array}{l}\text { Perceptual Alterations Reported } \\
\text { (Size, Distance, and Shape) }\end{array}$ & Other Perceptual Disorders & Oculomotor Disorders & Site of Lesio \\
\hline $\begin{array}{l}\text { Holmes (1919) } \\
6 \text { cases }\end{array}$ & $\begin{array}{l}\text { Inability to judge relative } \\
\text { sizes. Overestimation of } \\
\text { distance }\end{array}$ & $\begin{array}{l}\text { Difficulty in counting objects } \\
\text { and in reading. Loss of stereo- } \\
\text { scopic vision (in one case) }\end{array}$ & $\begin{array}{l}\text { Difficulty in fixation, im- } \\
\text { paired accommodation and } \\
\text { convergence }\end{array}$ & $\begin{array}{l}\text { Bilateral, } \\
\text { posterior } \\
\text { (in all } \\
\text { cases) }\end{array}$ \\
\hline $\begin{array}{l}\text { Holmes and } \\
\text { Horrax }(1919) \\
1 \text { case }\end{array}$ & $\begin{array}{l}\text { Inability to judge apparent size. } \\
\text { Absolute and relative dis- } \\
\text { tance judgment severely } \\
\text { impaired }\end{array}$ & $\begin{array}{l}\text { Loss of topographical memory, } \\
\text { loss of topographical orien- } \\
\text { tation, inability to perceive } \\
\text { movement, reading and count- } \\
\text { ing difficulties, loss of stereo- } \\
\text { scopic vision }\end{array}$ & $\begin{array}{l}\text { Difficulty in fixation, im- } \\
\text { paired accommodation and } \\
\text { convergence }\end{array}$ & $\begin{array}{l}\text { Bilateral, } \\
\text { posterior }\end{array}$ \\
\hline $\begin{array}{l}\text { Riddoch }(1935) \\
2 \text { cases }\end{array}$ & $\begin{array}{l}\text { Inability to judge distance in } \\
\text { homonymous half-fields of } \\
\text { apparently normal fields of } \\
\text { vision }\end{array}$ & None reported & $\begin{array}{l}\text { Impairment of conjugate de- } \\
\text { viation to right }\end{array}$ & $\begin{array}{l}\text { Unilateral, } \\
\text { parietal, } \\
\text { posterior } \\
\text { (left) }\end{array}$ \\
\hline $\begin{array}{c}\text { Brain }(1941) \\
3 \text { case }\end{array}$ & $\begin{array}{l}\begin{array}{l}\text { Inability to judge distance } \\
\text { accurately in crossed }\end{array} \\
\text { homonymous half-fields, } \\
\text { otherwise apparently nor- } \\
\text { mal }\end{array}$ & $\begin{array}{l}\text { Unilateral spatial agnosia } \\
\text { (in two cases) } \\
\text { Apraxia for dressing, right-left } \\
\text { disorientation } \\
\text { Loss of topographical memory } \\
\text { (in one case) }\end{array}$ & None & $\begin{array}{l}\text { Unilateral, } \\
\text { posterior } \\
\text { (2 right, } \\
1 \text { left) }\end{array}$ \\
\hline $\begin{array}{l}\text { Paterson and } \\
\text { Zangwill (1944) } \\
1 \text { case }\end{array}$ & $\begin{array}{l}\text { Difficulty in estimating abso- } \\
\text { lute and relative distance in } \\
\text { left upper quadrants of the } \\
\text { visual fields }\end{array}$ & $\begin{array}{l}\text { Visual inattention. Agnosia for } \\
\text { left side of space. Visual con- } \\
\text { structive disabilities }\end{array}$ & None & $\begin{array}{l}\text { Unilateral, } \\
\text { occipital } \\
\text { (right) }\end{array}$ \\
\hline $\begin{array}{l}\text { Symonds (1946) } \\
1 \text { case }\end{array}$ & Difficulty in judging distance & None reported & None & $\begin{array}{l}\text { Unilateral, } \\
\text { posterior }\end{array}$ \\
\hline $\begin{array}{l}\text { Bender and } \\
\text { Teuber }(1948) \\
2 \text { cases }\end{array}$ & $\begin{array}{l}\text { Changes in apparent size and } \\
\text { shape, inability to judge dis- } \\
\text { tance, limited to amblyopic } \\
\text { parts of visual fields }\end{array}$ & Visual constructive disability & None & $\begin{array}{l}\text { Unilateral, } \\
\text { posterior } \\
\text { (right in } \\
\text { both case }\end{array}$ \\
\hline $\begin{array}{l}\text { McFie et al. } \\
\text { (1950) } \\
1 \text { case }\end{array}$ & $\begin{array}{l}\text { Inability to assess the distance } \\
\text { of near objects }\end{array}$ & $\begin{array}{l}\text { Visual constructive disabilities. } \\
\text { Neglect of left side of visual } \\
\text { space }\end{array}$ & Not mentioned & $\begin{array}{c}\text { Unilateral, } \\
\text { fronto- } \\
\text { parietal } \\
\text { (right) }\end{array}$ \\
\hline $\begin{array}{l}\text { Hecaen et al. } \\
\text { (1957) } \\
1 \text { case } \\
\text { Ettlinger et al. } \\
\text { (1957) } \\
2 \text { cases }\end{array}$ & $\begin{array}{l}\text { Impairment of relative dis- } \\
\text { tance judgment }\end{array}$ & $\begin{array}{l}\text { Rotation of visual coordinates. } \\
\text { Left-right disorientation. } \\
\text { Visual constructive disability } \\
\text { Visual constructive disability } \\
\text { Marked unilateral neglect } \\
\text { (in one case) }\end{array}$ & None & $\begin{array}{c}\text { (right) } \\
\text { Unilateral } \\
\text { parietal } \\
\text { (right) } \\
\text { Unilateral, } \\
\text { posteriafe } \\
\text { (right in } \\
\text { both case }\end{array}$ \\
\hline
\end{tabular}

Alterations of size and/or distance judgment in patients with parietal lesions have also been described by Riddoch (1935), Brain (1941), Paterson and Zangwill (1944), Symonds (1946), McFie, Piercy, and Zangwill (1950), Hécaen, Penfield, Bertrand, and Malmo (1956), and Ettlinger, Warrington, and Zangwill (1957). The relevant features of these case reports are summarized in Table $I$.

Abnormalities in the perception of size in cases of this type have seldom been interpreted as alterations of perception involving changes in the relations between the apparent size of objects and their distance from the observer. Further, concomitant disturbances of perception of size and distance occurring in the same patient have generally been considered as two unrelated problems. But in the belief that these phenomena might in fact be manifestations of altered perceptual constancy, and in the hope that their study would contribute to the analysis of the syndrome of spatial disorientation, a set of experiments on size constancy was designed as part of an investigation of disorders of visual perception associated with brain lesions. These experiments were intended to compare the size judgments of a group of patients having variously located bratio lesions with those of a control group of normal. subjects thereby throwing light on the central basis of size constancy.

\section{Method}

Selection of Subjects. - The clinical material comprised $\stackrel{\mathcal{Q}}{\mathbb{Q}}$ 39 patients, each with a verified, single, circumscribed $\stackrel{2}{\vec{F}}$ lesion involving part of the cerebral cortex. The lesion 3 was identified at operation in 36 of the cases, at necropsy in one case, and in two cases from radiographic evidence that clearly indicated the nature and location of an in-:operable tumour. None of these patients had significant intellectual impairment, disturbances of visual acuity, or clinically apparent abnormalities of oculomotor function: sufficient to affect their performance in the tests.

The pathological nature of the lesions fell into four main categories: Localized cortical excisions (15 cases); lobectomies (nine cases); neoplasms (eight cases); glial scars (six cases); and one case with an intracerebral $\frac{}{3}$ haematoma.

The control material comprised 30 healthy men and women, together with six patients with peripheral nerve $N$ injuries. The control subjects were selected to be within the same age range as that embracing the patients form- $N$ ing the clinical group, that is, between 16 and 65 years of $\mathrm{W}_{\mathrm{W}}$ 
age. They were also free from any visual or oculomotor defects, other than in a few cases refractive errors that were corrected with spectacles.

Allocation of Lesions.-Lesions were allocated to cortical sectors defined arbitrarily by the conventional anatomical boundaries (von Bonin, 1950), in terms of the site of the main bulk of the lesion. Where a lesion extended more or less equally between adjacent cortical sectors, it was allocated to both of them.

The final allocation of a lesion to a cortical sector was made by combining all the anatomical data available for each case, * such data being derived from the results of electroencephalography, cerebral angiography and air studies, together with the more detailed information provided at operation or necropsy. On this basis allocations were distributed, as shown in Table II, in terms of

TABLE II

ANATOMICAL LOCATION OF VERIFIED CORTICAL LESIONS IN 39 PATIENTS

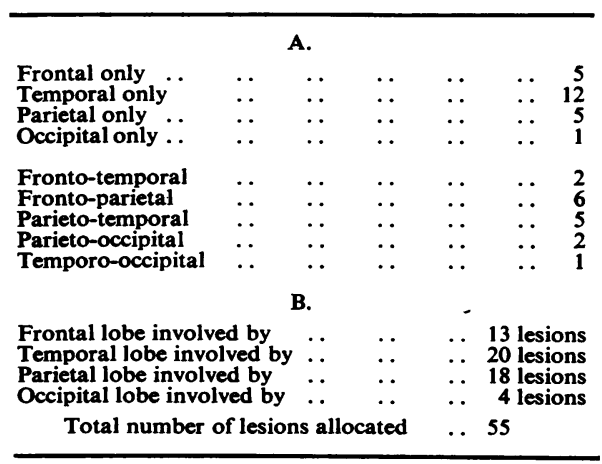

frontal, temporal, parietal, and occipital sectors, and in various paired combinations of these. This classification of lesions follows that proposed by Semmes, Weinstein, Ghent, and Teuber (1955).

Lesions were further classified in terms of their laterality, that is, whether in the right or left hemisphere.

Apparatus.-This consisted of a rectangular, blacklined box $3 \mathrm{~m}$. long, in which the stimulus and comparison objects were both mounted (Fig. 2).

The stimulus objects were presented at one side of the box, on the subject's left, at a distance of $100 \mathrm{~cm}$. from his eyes. These objects were evenly-illuminated triangles of two sizes, respectively $5 \mathrm{~cm}$. and $10 \mathrm{~cm}$. in vertical height.

The comparison object was fixed at $300 \mathrm{~cm}$. from the subject's eyes, at the other (right) side of the box. It also was an evenly-illuminated white triangle but its size could

\footnotetext{
*It is not to be supposed that such an allocation represents the total extent of the lesion in every instance, for in cases of neoplasms, especially the gliomata, this cannot be determined accurately. Instead, the method of allocation employed here is relative rather than absolute, the designated sector of the cortex being that most damaged by the lesion relative to adjacent sectors.
}

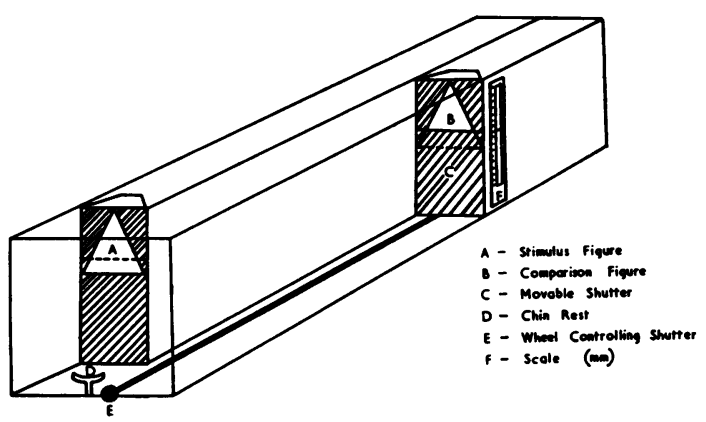

FIG. 2.-Cross-sectional diagram of apparatus employed for the measurement of size-constancy judgments.

be linearly adjusted by the subject through a remote drive operating a shutter moving vertically in front of the triangle until it appeared to be of the same size as the stimulus object. Movements of the screening shutter in either direction could be read off from a scale, mounted on the side of the box so that it was invisible to the subject. In choosing the comparison triangle a range of size variation exceeding, at both upper and lower limits, the physical sizes of the two stimulus objects was provided.

In this situation, the vertical height of the variable comparison triangle had to be adjusted to $5 \mathrm{~cm}$. and $10 \mathrm{~cm}$. respectively for equality of physical size with each of the stimulus triangles, and to $15 \mathrm{~cm}$. and $30 \mathrm{~cm}$. respectively for equality of size of retinal image, i.e., of visual angle.

The angular separation between the centre of the stimulus triangle in situ and the centre of the comparison triangle, subtended at the mid-point between the subject's eyes, was $9^{\circ}$.

The subject's head was steadied on a chin rest, secured to the base of the rectangular box.

The interior of the box, and the contained fittings, were coated with a non-reflective black paint to prevent the observer basing his judgments on the size of the shutter needed to reduce or enlarge the comparison object to the required size. Comparison of the stimulus objects with familiar objects was prevented, as far as possible, by keeping the testing room in darkness, only the interior of the box being illuminated. Special care was taken that the intensity and distribution of illumination within the box were such as to permit the subject to assess the distance between the stimulus and comparison objects.

Instructions.-The instructions given to the subject required him to look back and forth between the stimulus and comparison objects, while adjusting the size of the latter until the two objects were judged to be equal.

The instructions were framed with the purpose of emphasizing to the subject the necessity of considering the real physical, i.e., measured, size of the objects, and were as follows:

"There (pointing to the stimulus triangle of either $5 \mathrm{~cm}$. or $10 \mathrm{~cm}$. height) you see a triangle." 
"There (pointing to the comparison triangle) to your right, and further away, is another triangle that can be varied in size by means of this wheel" (pointing to the wheel within the subject's reach).

"Please adjust it by turning the wheel until the triangles look to you to be the same actual size, that is, as if you were comparing them by measuring them."

The subject's adjustments of the size of the variable comparison triangle were randomly varied between larger to equality, and smaller to equality. In half of the trials he was allowed to begin from larger, and in half from smaller, preliminary settings of the shutter. In both cases he was allowed to make fine adjustments of the shutter, up and down, until he expressed himself satisfied with the match.

Each observer made six judgments with binocular and six judgments with monocular vision. These trials were also varied in a random way. In the monocular judgments the preferred eye was always used, this being determined beforehand by a test of eye dominance.

In the circumstances of this experiment, the comparison triangle would have to be adjusted to a height of $5 \mathrm{~cm}$. for equality of physical size and to $15 \mathrm{~cm}$. for equality of retinal size. In Fig. 1 triangle (s) represents the stimulus object $100 \mathrm{~cm}$. from the nodal point of the eye (n). The triangles (c) and (b) to the left represent the comparison object, $300 \mathrm{~cm}$. from (n). If the subject is to make a constancy judgment, then he should adjust the comparison triangle to the dimensions of (c); but should he make a retinal image judgment, then he will adjust the comparison triangle to the dimensions of (b) so that it subtends at the retina an image of the dimensions of (a).

Analysis of Results.-The individual judgments of size by each subject were measured in centimetres on the scale attached to the side of the box. The values obtained in each of six trials were added, and the means calculated. The result of each experiment was then expressed in terms of an average error of deviation from constancy, irrespective of the actual sign of the error. In other words, the mean error was referred theoretically to absolute constancy represented by zero error. Means and standard deviations were obtained in this way for each of the patients and for each of the normal control subjects in conditions both of binocular and monocular vision.

Five separate analyses of variance were made for each experiment, following the method proposed by Semmes et al. (1955), as follows:-

(a) Controls vs frontal vs non-frontal lesions

(b) Controls vs temporal vs non-temporal lesions

(c) Controls vs parietal vs non-parietal lesions

(d) Controls $v s$ right-sided lesions $v s$ left-sided lesions

(e) Controls vs patients with visual field defects vs patients without visual field defects

Statistical comparisons involving the group of patients with occipital lobe lesions were not made, as there were only four such cases, and only one of these patients had a purely occipital lesion, the other three having posterior extensions of lesions located primarily in the temporal or parietal lobes.

\section{Results}

With Binocular Vision.-The means of the average errors of judgment (and their standard deviations)

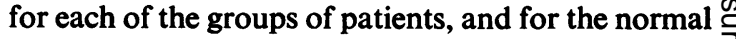
control group, are listed in Table III. The results

TABLE III

SIZE JUDGMENT WITH BINOCULAR VISION

A.

\begin{tabular}{|c|c|c|c|c|c|}
\hline \multirow{2}{*}{ Groups } & \multirow{2}{*}{$\begin{array}{c}\text { No. of } \\
\text { Subjects }\end{array}$} & \multicolumn{2}{|c|}{$5 \mathrm{~cm}$. Figure } & \multicolumn{2}{|c|}{$10 \mathrm{~cm}$. Figure } \\
\hline & & Means & S.D. & Means & S.D. \\
\hline $\begin{array}{l}\text { Controls } \\
\text { Frontal lesions } \\
\text { Temporal lesions } \\
\text { Parietal lesions } \\
\text { Occipital lesions }\end{array}$ & $\begin{array}{r}36 \\
13 \\
20 \\
18 \\
4\end{array}$ & $\begin{array}{l}0.63 \\
0.64 \\
0.99 \\
1.17 \\
1.52\end{array}$ & $\begin{array}{l}0.48 \\
0.41 \\
0.88 \\
0.96 \\
0.79\end{array}$ & $\begin{array}{l}1.38 \\
1.61 \\
1.74 \\
2.49 \\
1.63\end{array}$ & $\begin{array}{l}1.03 \\
1.61 \\
1.44 \\
1.72 \\
1.62\end{array}$ \\
\hline $\begin{array}{l}\text { Right-sided lesions } \\
\text { Left-sided lesions }\end{array}$ & $\begin{array}{l}19 \\
20\end{array}$ & $\begin{array}{l}0.88 \\
0.94\end{array}$ & $\begin{array}{l}0.66 \\
0.87\end{array}$ & $\begin{array}{l}1.84 \\
1.73\end{array}$ & $\begin{array}{l}1.53 \\
1.49\end{array}$ \\
\hline $\begin{array}{l}\text { Patients with visual } \\
\text { field defects } \\
\text { Patients without } \\
\text { visual field defects }\end{array}$ & 11 & $1 \cdot 32$ & 1.07 & 1.83 & $1 \cdot 36$ \\
\hline
\end{tabular}

B.

\begin{tabular}{|c|c|c|c|}
\hline Groups & d.f. & $\mathbf{t}$ & Significance \\
\hline $\begin{array}{l}\text { Controls vs frontal lesions } \\
\text { Controls vs temporal lesions } \\
\text { Controls vs parietal lesions }\end{array}$ & $\begin{array}{l}47 \\
54 \\
52\end{array}$ & $\begin{array}{l}0 \cdot 35 \\
1.56 \\
2 \cdot 82\end{array}$ & $\begin{array}{c}\text { None } \\
\text { None } \\
\text { At } 0.01 \text { level }\end{array}$ \\
\hline
\end{tabular}

are shown graphically in Fig. 3. (It should pointed out that the group of patients showed $g$ c greater scatter of the six individual judgments each instance than did the control subjects, but the difference is not statistically significant.)

The performance of the group of patients with lesions involving the parietal lobe is significantly different from that of the control group $(t=2 \cdot 82$; significant at the 0.01 level of confidence) in that their judgments deviated significantly from constancy. Size judgments by the former group are $\AA$ also further from constancy than those of all other $\vec{B}$ patients at the 0.02 level of confidence $(t=2.35)$. However, the performance of each of the groups of $\supset$ patients with lesions elsewhere than in the parietal lobe is not significantly different from that of the control group.

Analysis of the results in terms of the laterality of the lesions reveals no significant difference $(F=1 \cdot 45)$ between errors made by the patients with right-sided lesions and those made by patients with left-sided lesions.

Consideration of the results in relation to the occurrence of visual field defects reveals no con- $\frac{T}{O}$ sistently significant association. For example, with the $5 \mathrm{~cm}$. figure a comparison of the errors made by $N$ patients having visual field defects with those made $N$ by patients without such defects shows them to be 


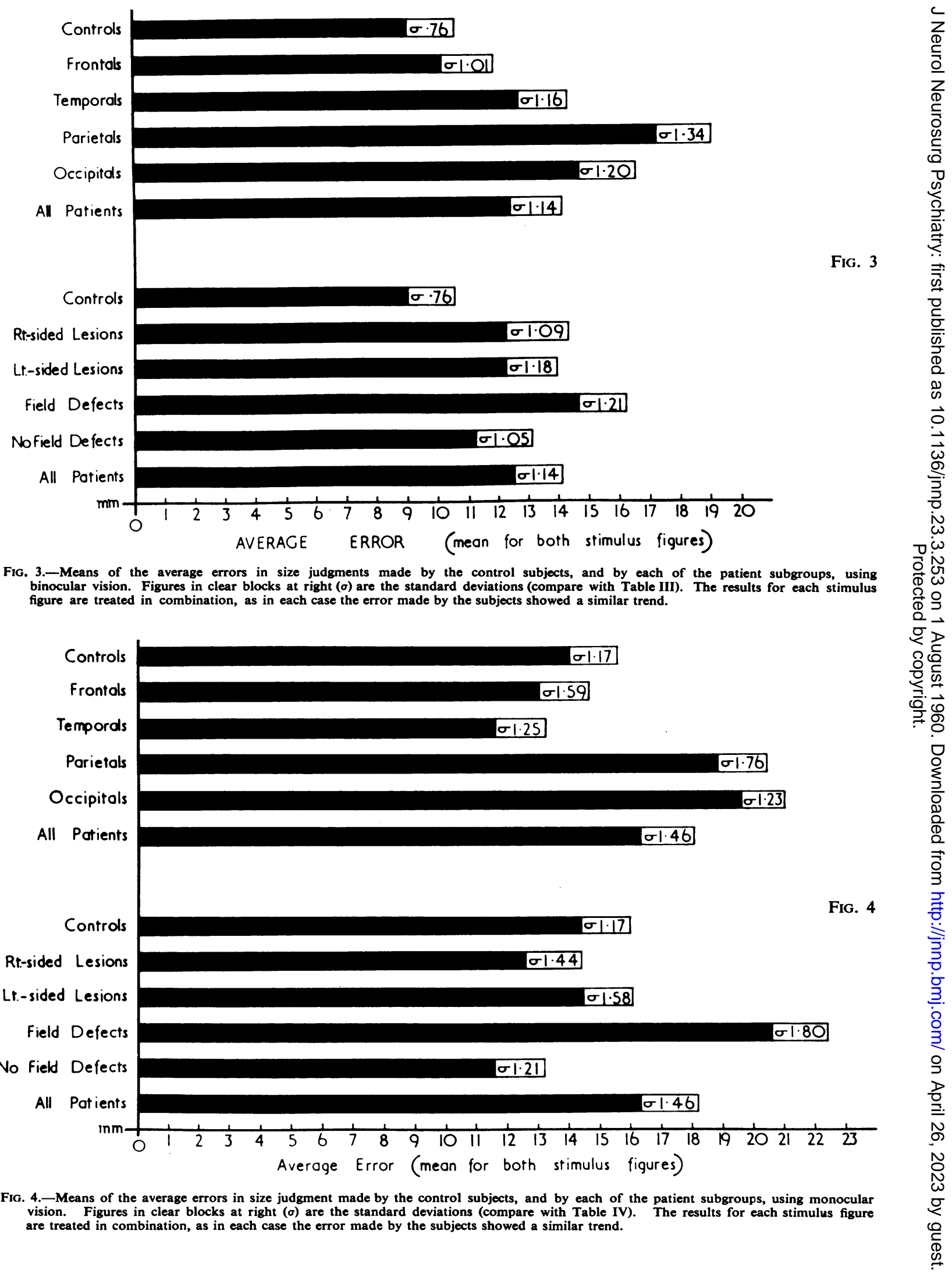


significantly greater $(t=2 \cdot 13$; significant at the 0.05 level of confidence) in the former group. On the other hand, there is no significant difference between the same two groups of patients, when the $10 \mathrm{~cm}$. triangle is employed.

With Monocular Vision.- The means and standard deviations of the errors made with monocular judgments of size are shown in Table IV. The results are displayed graphically in Fig. 4.

TABLE IV

SIZE JƯDGMNT WITH MONOCULAR VISION

A.

\begin{tabular}{|c|c|c|c|c|c|}
\hline \multirow{2}{*}{ Groups } & \multirow{2}{*}{$\begin{array}{l}\text { No. of } \\
\text { Subjects }\end{array}$} & \multicolumn{2}{|c|}{$5 \mathrm{~cm}$. Figure } & \multicolumn{2}{|c|}{$10 \mathrm{~cm}$. Figure } \\
\hline & & Means & S.D. & Means & S.D. \\
\hline $\begin{array}{l}\text { Controls } \\
\text { Frontal lesions } \\
\text { Temporal lesions } \\
\text { Parietal lesions } \\
\text { Occipital lesions }\end{array}$ & $\begin{array}{r}36 \\
13 \\
20 \\
18 \\
4\end{array}$ & $\begin{array}{l}1 \cdot 13 \\
1 \cdot 42 \\
1 \cdot 01 \\
1 \cdot 71 \\
1 \cdot 88\end{array}$ & $\begin{array}{l}0.77 \\
1.51 \\
1.03 \\
1.71 \\
0.57\end{array}$ & $\begin{array}{l}1.91 \\
1.40 \\
1 \cdot 51 \\
2.31 \\
2.69\end{array}$ & $\begin{array}{l}1.58 \\
1.67 \\
1.46 \\
1.82 \\
1.90\end{array}$ \\
\hline $\begin{array}{l}\text { Right-sided lesions } \\
\text { Left-sided lesions }\end{array}$ & $\begin{array}{l}19 \\
20\end{array}$ & $\begin{array}{l}1 \cdot 18 \\
1 \cdot 26\end{array}$ & $\begin{array}{l}1 \cdot 25 \\
1 \cdot 57\end{array}$ & $\begin{array}{l}1 \cdot 56 \\
1 \cdot 84\end{array}$ & $\begin{array}{l}1.63 \\
1.60\end{array}$ \\
\hline $\begin{array}{l}\text { Patients with visual } \\
\text { field defects } \\
\text { Patients without } \\
\text { visual field defects }\end{array}$ & $\begin{array}{l}11 \\
28\end{array}$ & $\begin{array}{l}1.91 \\
0.95\end{array}$ & $\begin{array}{l}1.68 \\
1.04\end{array}$ & $\begin{array}{l}2.48 \\
1.40\end{array}$ & $\begin{array}{l}1.93 \\
1.38\end{array}$ \\
\hline
\end{tabular}

B.

\begin{tabular}{c|c|c|c}
\hline \multicolumn{1}{c|}{ Groups } & d.f. & $t$ & Significance \\
\hline Controls vs frontal lesions & 47 & 0.78 & None \\
Controls vs temporal lesions & 54 & 0.68 & None \\
Controls vs parietal lesions & 52 & 1.71 & None \\
Controls t non-parietal & 73 & 1.99 & At 0.05 level \\
lesions vs parietal lesions & 73 & & \\
\hline
\end{tabular}

The findings are slightly different from those described for binocular judgments. As with binocular vision, there is no significant difference between the scores of the control group and those of the group of patients as a whole in conditions of monocular vision; nor is there any significant difference between the score of any one patient subgroup and that of the control group.

However, there is a difference (significant at the 0.05 level of confidence) between the performance of the group of patients with parietal lesions and that of the remainder of the patients grouped together. This apparent discrepancy is due to the fact (see Fig. 4) that the mean scores of the two groups of patients with temporal and frontal lobe lesions are each slightly better than the score of the control group. But if the performance of the parietal group be compared with that of the control group plus the patients without parietal lesions (pooled together), there is then a difference between the two categories, that is, significant at the 0.05 level of confidence $(t=1.99)$, as shown in Table IV.
Analysis of the results according to the laterality of the lesion again reveals no significant difference $\underline{0}$ between the scores of patients with right-sided $Z$ lesions and those of patients with left-sided lesions.

Analysis of the results with respect to the occur- of rence or otherwise of visual field defects gives the same findings as with binocular vision, viz., no consistent correlation.

Relative Importance of Location of Lesion and of Visual Field Defects in Influencing Size Judgments. In view of the fact that of the 18 patients with: parietal lobe lesions five had visual field defects, it is important to establish whether the presence of a parietal lesion or of a visual field defect is the more directly related to alterations of size constancy. This is especially necessary as there is evidence (see $\mathbb{\widetilde { D }}$ above) that patients with visual field defects may display alterations in size judgment in some conditions of the experiment.

In an attempt to evaluate the relative significance of these two factors, an analysis of variance was $\vec{O}$ performed in a manner similar to that proposed by Weinstein, Semmes, Ghent, and Teuber (1956) by subdividing the patient group in terms of the presence i⿱ or absence of parietal lesions, and in terms of the $\omega$ presence or absence of visual field defects.

The highest mean score, i.e., the greatest deviation $\omega$ from size constancy, was produced by a combinâf tion of a parietal lesion and a visual field defect $\mathrm{m}$ conditions both of binocular and of monocular vision. Below these was the mean error made byco patients with parietal lobe lesions, but witho on visual field defects. The scores of the remaining ture patient groups, i.e., those with visual field defects but without parietal lesions and those with nonparietal lesions, and normal fields of vision, were each closer in value to those of the control group. The results of $t$ tests performed on the scores of patients with a parietal lesion plus a visual field $\odot$ defect and with parietal lesions without a visual 0 field defect reveal no significant difference between $\overrightarrow{\bar{O}}$ these two groups in any of the conditions of the experiment.

Direction of Errors of Size Judgment in Patients with Parietal Lesions.-In order to determine whether the judgments made by patients with parietal lobe lesions deviated towards over-constancy, or towards the size of the retinal image, the following procedure was employed. (In the circumstances of these experiments, an "over-constancy" judgment is given when the subject makes the variable comparison triangle smaller than the nearer standard; and a retinal image judgment when he makes the variable triangle larger than the $N$ standard.) 
The absolute values of the size judgments made by each member of the control group in each of the experimental circumstances, i.e., with each stimulus figure, and with both binocular and monocular vision, were tabulated, and the means and standard deviations calculated. From these data, symmetrical confidence limits for the control group were established by using a 2-tail $t$ test at a 0.01 level of confidence.

Size judgments made by patients with parietal lesions that exceeded the upper limit of confidence for those made by the control group of subjects were classified as abnormal deviations towards the retinal image (ADRI); while results below the lower limit of confidence for the control subjects were classified as abnormal deviations towards over-constancy (ADOC).

Independent analysis of the findings for each of the various conditions of experiment applied to the parietal cases shows that only in one such condition (binocular viewing of the $10 \mathrm{~cm}$. figure) is the $\chi^{2}$ value significant at the 0.01 level of confidence when comparing the incidence of ADOC and ADRI judgments. Nevertheless, in all experimental circumstances the trend of the size judgments made by patients with parietal lesions is in the direction of over-constancy; and if the results in all conditions of the experiment be taken together, then the cases with parietal lobe lesions do show a significant tendency to make over-constancy judgments. For example (see Table V), out of a total of 45 mean

TABLE V

CATEGORIES OF ABNORMAL SIZE JUDGMENTS MADE BY PARIETAL CASES

A.

\begin{tabular}{|c|c|c|}
\hline $\begin{array}{l}\text { Total number of mean judgments } . . \\
\text { Normal deviations from constancy .. } \\
\text { Abnormal deviations from constancy } \\
\text { Abnormal deviations to over-constancy } \\
\text { Abnormal deviations to retinal image } \\
\qquad x^{2}=6.42 \text { (significant at } 0.02 \text { lev }\end{array}$ & $\begin{array}{l}\cdots \\
\cdots \\
\cdots \\
\cdots \\
\text { vel) }\end{array}$ & $\begin{array}{ll}\ldots & 72 \\
\cdots & 27 \\
\ldots & 45 \\
\cdots & 31 \\
\ldots & 14\end{array}$ \\
\hline
\end{tabular}

B.

\begin{tabular}{|c|c|c|}
\hline $\begin{array}{l}\text { Marked abnormal deviations to over- } \\
\text { constancy... } \\
\text { Moderate abnormal deviations to over- } \\
\text { constancy... } \\
\begin{array}{l}\text { Marked abnormal deviations to retinal } \\
\text { image } \ldots\end{array} . .\end{array}$ & $\begin{array}{l}8 \text { cases } \\
3 \text { cases } \\
3 \text { cases }\end{array}$ & $\begin{array}{c}x^{2}=4.58 \\
\text { (significant at } \\
0.05 \text { level) }\end{array}$ \\
\hline
\end{tabular}

judgments made by those parietal cases that deviated abnormally from constancy, 31 were ADOC judgments, while only 14 were ADRI judgments. The $\chi^{2}$ value for this comparison is 6.42 , which is significant at the 0.02 level of confidence.

In terms of these criteria, the size judgments made by the patients with parietal lesions may be classified as follows:-
Eight patients gave marked ADOC judgments; three gave moderate ADOC judgments; three gave marked ADRI judgments; and none gave moderate ADRI judgments. Alterations are arbitrarily designated as "marked" when abnormal deviations from constancy were evident in three or more conditions of the experiment and as "moderate" when such judgments were given in two of the four conditions of the experiment. The $\chi^{2}$ value for the relevant comparison of these groups is 4.58 and this is significant at the 0.05 level of confidence (Table V).

These observations indicate that the abnormal variations from constancy in the size judgments made by patients with parietal cortical lesions are more usually deviations towards over-constancy than towards retinal-image size.

Clinical Observations. - The principal clinical abnormalities of visual space perception encountered in this series of patients with lesions involving the parietal lobes were as follows:-

(i) Unilateral spatial neglect in three patients with lesions in the right parietal lobe.

(ii) Visuo-constructive defects (of the type described by Ettlinger et al., 1957) in 10 of the cases. The visuo-constructive impairment varied in severity, being marked in two of the cases and moderate in the remaining eight. All patients with evidence of visuo-constructive disabilities showed some degree of abnormal deviation from constancy when making size judgments, but there were four patients with abnormal deviations from size constancy who did not display any abnormality when performing visuoconstructive tests.

(iii) "Spatial thought" disorder (see McFie et al., 1950) was evident in five cases. These patients also showed some degree of abnormal deviation from constancy in making size judgments.

\section{Discussion}

The results of this study indicate that size constancy, in conditions both of binocular and monocular vision, is disturbed significantly only when lesions involve the parietal cortical sector of either hemisphere. These disturbances are independent of the presence or absence of visual field defects, suggesting that they are to be ascribed to a perceptual disorder at a central level. These findings are consistent with earlier evidence (cf. Ettlinger et al., 1957) that the parietal cortex bears a special relationship to spatial orientation with regard to the external world.

The results further suggest that alterations in the perception of size, such as are reported clinically in many cases of spatial disorientation, may well depend in part on a disturbance of the constancy mechanism.

Explanations of the nature of the clinically 
observed disturbances of visual perception of size and distance have so far varied considerably. Holmes (1919), for example, stated that in his cases the afferent systems from the labyrinths and from the ocular and other muscles were unimpaired, and that therefore the visual symptoms "must be attributed either to a disturbance of the local sign functions of the retina, or to a failure of the brain to associate and integrate these with other afferent impressions". According to Holmes, there were in his cases "many direct observations showing that the retinal local signs were affected" but he did not specify what these direct observations were.

Riddoch (1935) concluded that the estimation of relative and absolute distance is the result of the integration of immediate sensations from the retina with accumulated past experience.

On the other hand, Ettlinger et al. (1957) suggested that perceptual abnormalities in cases with spatial disorientation are not wholly due to defects of sensory function; and they thought it reasonable to ascribe them to impairment of "higher levels of neurological integration". In their view, the essential defect lies not in a disturbance of sensory input (as proposed by Bay, 1953) but in a failure to make use of this input at a "central level".

The majority of authors stress the fact that disorders of visual perception may occur in the absence of sensory deficits in the primary visual afferent system. But they have not suggested that afferent impulses arising from receptors in the extra-ocular muscles may contribute to the perception of size at different distances, i.e., to size constancy, although hypotheses involving such a concept have frequently been proposed in the past in connexion with other aspects of visual experience. In the perception of the size of objects viewed at different distances, the size of the retinal image per se cannot provide satisfactory cues for distance (e.g., see Graham, 1951); and it may be that afferent impulses generated by retinal stimulation are complemented coincidently in the brain by discharges related to the degree of convergence of the eyeballs that occurs during fixation. These latter discharges might then provide a major cue for judging the distance between two objects being viewed, and so play a part in making constancy judgments. In other words, it might be that a constancy judgment results if, when the pattern of retinal impulses changes because of the unequal sizes of the retinal images of the same object seen at different distances, afferent discharges from the external ocular muscles simultaneously provide information of the distance between the two objects producing the retinal images.

Although it is now clear that human extrinsic ocular muscles contain receptors that are probably $W Y K E$
capable of responding to changes in tension induced
by varying degrees of ocular convergence $(e . g .$, see Cooper, Daniel, and Whitteridge (1955), the role of such receptors in space perception has long been 0 ) questioned (see Ludvigh, 1952). Nevertheless, the experimental and anatomical evidence now avail- 0 able (e.g., Cooper et al., 1955) is sufficient to make it a reasonable hypothesis that ocular convergence? in man fires afferent discharges from the eye muscles $\stackrel{\overrightarrow{0}}{\rightleftharpoons}$ into the brain, and that these eventually reach areas.. of the cortex, i.e., the parieto-occipital sectors, to $\overrightarrow{\vec{F}}$ which impulses of retinal origin are also directed. Cortical interpretation of these two sets of impulses, i.e., of retinal origin, and from receptors in the extra- $\frac{\bar{y}}{\bar{c}}$ ocular muscles, might then contribute to size $\frac{\tilde{\sigma}}{\widetilde{\alpha}}$ constancy judgments, the data from the ocular muscle receptors modifying as it were coincidentalis information from the retinal receptors.

If this hypothesis be tenable, it is possible that lesions in the parieto-occipital cortical sectors might $\vec{\omega}$ result in alterations of size constancy judgments? because cues normally provided by afferent discharges evoked from ocular muscle receptors can no longer be coordinated with cues provided by the $\omega$ primary retinal afferent systems.

Abnormalities in size constancy judgments might then be regarded in a similar way to those of spatialo orientation as proposed by Ettlinger et al. (1957) Qs. "an impairment of higher levels of neurological $\square$ integration". That is, they represent the result gto disordered integration within the parieto-occipitales regions of the cerebral cortex of two sets of afferent $\overrightarrow{\vec{\theta}}$ inputs.

One further aspect of the present findings requires. comment, namely, the phenomenon of over-? constancy displayed by 11 of the 18 patients with lesions involving the parietal cortical sector.

Over-constancy in size judgments has previouslyo been reported in several experimental studies on normal individuals, especially when using large distances (Smith, 1953). This was first interpreted in terms of space error; but lately it has been suggested (see Smith, 1953) that over-constancyọ. judgments are the result of an improper estimation of distance, for Smith pointed out that should distance perception err in the direction of over $-\overline{0}$ estimation, then size judgments deviate in the direction of over-constancy.

This interpretation, if applied to the present results, might suggest that the group of patients witho parietal lesions showed a tendency to over-constancy because of errors of distance judgment Before this explanation is acceptable, it would be necessary to carry out independent studies of dis- No tance perception in patients with parietal lesions N Studies of depth perception in the present group of 
subjects with parietal lesions (Wyke, 1959) failed to throw light on this problem.

However, it is relevant to note that one finding common to all experimental studies in which overconstancy has been reported is that the degree of over-estimation of size increases in proportion to the distance between the two objects whose size is being compared (see Gilinsky, 1955). Such observations may indicate that in circumstances when ocular convergence is operating significantly, size constancy judgments tend more towards constancy, whereas they deviate more markedly in the direction of over-constancy as convergence becomes less significant in the circumstances of observation. This in turn accords with the view here being proposed, viz., that afferent discharges from extraocular muscles contribute to the making of size constancy judgments.

\section{Summary}

An experimental study of size constancy, under binocular and monocular conditions, was undertaken in 39 patients with verified lesions in various sectors of the cerebral cortex, and in 36 healthy control subjects.

Significant deviations from normal size judgments were found to be associated specifically with lesions involving the parietal sector of the cortex of either hemisphere, and were typically in the direction of over-constancy. The occurrence of such deviations was not found to be due to the presence of a visual field defect per se.

Some theoretical interpretations of the results are discussed.

Thanks are due to Dr. E. T. O. Slater, and the Institute of Neurology, National Hospital, Queen Square, for the facilities to conduct this study, to the members of the staff of the National Centre, Queen Square, and of the Neurosurgical Centre at the Brook Hospital, Woolwich, for allowing their cases to be studied.

Thanks are also due to Professor O. L. Zangwill for his helpful advice, to Professor David Slome for facilities provided, and to Dr. Peter Armitage and Dr. R. Audley for statistical advice.

The apparatus was constructed by Mr. S. P. Steward, of the Department of Physiology, Royal College of Surgeons of England.

\section{REFERENCES}

Bay, E. (1953). Brain, 76, 515.

Bender, M. B., and Teuber, H. L. (1947). Arch. Neurol. Psychiat. (Chicago), 58, 721.

, (1948) Ibid., 59, 39.

Bonin, G. von (1950). Essay On The Cerebral Cortex. Thomas, Springfield, Illinois.

Brain, W. R. (1941). Brain, 64, 244.

Cooper, S., Daniel, P. M., and Whitteridge, D. (1955). Ibid., 78, Ettlinger, G., Warrington, E., and Zangwill, O. L. (1957). Ibid., 80, 335

Gilinsky, A. S. (1955). Amer. J. Psychol., 68, 173.

Graham, C. H. (195i). In Handbook of Experimental Psychology, ed. S. S. Stevens, pp. 868-920. Wiley, New York.

Hécaen, H., Penfield, W., Bertrand, C., and Malmo, R. (1956). A.M.A. Arch. Neurol. Psychiat. 75, 400

Holmes, G. (1919). Brit. med. J., 1, 385.

, and Horrax (1919). Arch. Neurol. Psychiat. (Chicago), 1, 385. Ludvigh, E. (1952). A.M.A. Arch. Ophthal., 48, 436.

McFie, J., Piercy, M. F., and Zangwill, O. L. (1950). Brain, 73, 167.

Paterson, A., and Zangwill, O. L. (1944). Ibid., 67, 331 .

Penfield,W. (1947). In Psychiatric Research, ed. by C. K. Drinker and others. Harvard University Monographs in Medicine and Public Health, No. 9, pp. 83-99. Harvard University Press, Public Health, No.

- and Jasper, H. H. (1954). Epilepsy and the Functional Anatomy of the Human Brain. Churchill, London.

Riddoch, G. (1935). Brain, 58, 376.

Semmes, J., Weinstein, S., Ghent, L., and Teuber, H. L. (1955). J. Psychol. (Provincetown, Mass.), 39, 227.

Smith, W. M. (1953). Ibid., 35, 143.

Symonds, C. P. (1946). Trans. ophthal. Soc. (U.K.), 69, 3.

Vernon, M. D. (1952). A Further Study of Visual Perception. University Press, Cambridge.

Weinstein, S., Semmes, J., Ghent, L., and Teuber, H. L. (1956). J. Psychol. (Worcester, Mass.), 42, 249. Wyke, Maria (1959). Alterations of Size Constancy Associated with
Brain Lesions in Man. Ph.D. Thesis, University of London. 